\title{
Fish farming on riverbed ponds of the Azov- Kuban plain
}

\author{
Alexey Abramchuk ${ }^{1, *}$, Georgy Moskul ${ }^{1}$, Natalia Pashinova ${ }^{1}$, Dmitry Shumeyko ${ }^{1}$ and \\ Vladislav Tyurin ${ }^{1}$ \\ ${ }^{1}$ Kuban state University, 149, Stavropol str., 350040, Krasnodar, Russia
}

\begin{abstract}
The article presents calculations and recommendations for fisheries development and improvement of fish productivity of riverbed ponds of the Azov-Kuban plain on the example of the Kirpili river. We studied the taxonomic composition and calculated the biomass of the natural fish food base of the studied reservoirs, which includes: phytoplankton- $383.5 \pm 0.24 \mathrm{~kg} / \mathrm{ha}$; zooplankton- $86.8 \pm 1.14 \mathrm{~kg} / \mathrm{ha}$; zoobenthos $-28.7 \pm 1.30 \mathrm{~kg} / \mathrm{ha}$, macrophytes - from 10 to $45 \mathrm{~kg} / \mathrm{m}^{2}$. The species composition of the Kirpili river ichthyofauna includes 11 species of fish. With the aim of pasture aquaculture stocking of channel ponds lowland rivers it is necessary to produce fingerlings Hypophthalmichthys molitrix, Hypophthalmichthys nobilis, Ctenopharyngodon idella, and as addition Cyprinus carpio, Mylopharyngodon piceus, Liza haematocheila, Polyodon spathula, etc.) individual weight below $25-30 \mathrm{~g}$, which will allow you to fish more $1350,0 \mathrm{~kg} / \mathrm{ha}$.
\end{abstract}

\section{Introduction}

The territory of the North-Western Caucasus has a significant amount of water resources, represented by internal reservoirs (rivers, estuaries, lakes) and waters of the Black and Azov seas. Many of them are undergoing significant operational stress, due to the intake of water for irrigation and water supply of agricultural and industrial enterprises. Against the background of the negative dynamics of the volume of catch of commercial fish species in the Black and Azov seas, the issue of development of freshwater pasture aquaculture, whose products will make it possible to meet the market demand not only in the territory of the Krasnodar territory but also abroad, is relevant. The most promising in this regard are the channel ponds of the Azov rivers (Eya, Chelbas, Beysug, Kirpili, Ponura, Albashi, Ash, and their tributaries). These watercourses are located within the Azov-Kuban oblique plain, heading in a North-westerly direction, through a system of estuaries flow into the sea of Azov.

As a result of large-scale work necessitated by the need to ensure the development of agriculture in the region and reduce flood activity, in the middle of the XX century, blocking dams and dams were built on the steppe rivers. At the moment, these watercourses

* Corresponding author: apilab@yandex.ru 
are a chain of riverbed ponds with an area ranging from several hectares to several hundred hectares. The total number of such isolated riverbed ponds is about two thousand, with a total area of more than 49 thousand hectares and a water volume of 697.6 million $\mathrm{m}^{3}$. These rivers are fed mainly by precipitation, ground and subsurface water (springs) [1].

In terms of fisheries, flat rivers are not fully used, just over half of the areas suitable for growing fish are operated by aquaculture organizations and private entrepreneurs. This also causes a very low fish productivity, which on average for these water bodies is no more than $10 \mathrm{~kg} / \mathrm{ha}$. at the same time, in some fish farms, where the entire range of fishbreeding and reclamation works is competently planned and systematically performed, the fish productivity exceeds the average by a hundred times or more, amounting to $1200 \mathrm{~kg} / \mathrm{ha}$ or more.

The relevance of the development of pasture fish farming based on the rational use of the natural biological potential of riverbed ponds of steppe rivers is also due to high economic costs for the necessary resources of industrial aquaculture (feed, electricity, etc.) $[2,3,4]$. Naturally formed forage organisms of reservoirs, with balanced stocking, allow you to fully, without making specialized feed and additional costs, ensure the trophic needs of cultivated fish [5,6]. The development of unicellular algae, invertebrates and higher aquatic plants in the southern regions of Russia is quite intensive, but they are mainly used by low-value fish species (Rutilus rutilus, Scardinius erythrophthalmus, Blicca bjoerkna, Carassius carassius, Alburnus alburnus, Gobio gobio, Tinca tinca, Gymnocephalus cernuus, etc.), which give low-quality fish products [7].

The purpose of the work is to increase the fish productivity of riverbed reservoirs of the Azov-Kuban plain.

Research problem:

- study the hydrological and hydrochemical parameters of the Kirpili river;

- study the zoo and phytoplankton, zoobenthos and ichthyofauna of the Kirpili river and assess the trophic capabilities of the reservoir for commercial aquaculture purposes;

- develop measures to increase the fish productivity of riverbed reservoirs based on specific environmental conditions.

In 2018-2019, comprehensive studies were carried out on the reservoirs of the Kirpili river, in the basin of which there are many hydraulic structures, in order to develop measures for the fishery development and increase the fish productivity of riverbed reservoirs.

\section{Research material and methods}

Collection and processing of hydrological, hydrochemical, hydrobiological and ichthyological material was carried out in accordance with generally accepted methods. The sampling scheme and its quantitative characteristics are shown in table 1 .

We determined the speed of water flow, its temperature, the width of the watercourse, and the depth. Hydrochemical studies included determining the concentration of oxygen in water, as well as the main characteristics of its chemical composition.

Phytoplankton was collected in a plastic container submerged in water to a depth of 5$10 \mathrm{~cm}$. the Sample was fixed with iodine until the water acquired a stable yellow color. Cameral processing of samples was performed after their settling in order to ensure complete settling of cells.

Counting of algal cells produced in the chamber of Nagata with subsequent re-counting their numbers per $1 \mathrm{~m}^{3}$. Determination of algae biomass was carried out using the volumeweight method. 
Zooplankton samples were collected by the Apstein network, which filtered 100 liters of water. The net was made of gas sieve № 72. Zooplankton samples were concentrated in a mesh Cup, then poured into a plastic container and fixed with a $70 \%$ alcohol solution.

Laboratory processing of zooplankton samples was carried out using the generally accepted counting and weighing method. The samples were viewed using the biolam stereoscopic microscope in the Bogorov chamber. The study of the taxonomic composition and quantitative development of bottom invertebrates was carried out using a hydrobiological net (the width of the working part is $30 \mathrm{~cm}$ ), which allows effectively selecting organisms of EPI - and infauna of loose soils. The selected samples were washed through mill gas №32.

Collected bottom invertebrates were recorded in 70-degree alcohol. In the process of further post-processing, they were divided into taxonomic groups, counted and weighed. Before weighing, the organisms were dried on filter paper to remove excess external moisture. Then the number and biomass of organisms of a certain taxonomic group were recalculated per $1 \mathrm{~m}^{2}$ of the river bottom.

Table 1. Sampling locations and number of samples taken on the Kirpili river.

\begin{tabular}{|c|c|c|c|c|c|}
\hline \multirow{2}{*}{$\begin{array}{c}\text { The sampling } \\
\text { site }\end{array}$} & \multicolumn{5}{|c|}{ Number of samples, units. } \\
\cline { 2 - 6 } & hydrological & hydrochemical & $\begin{array}{c}\text { Hydrobiological } \\
\text { phytoplank } \\
\text { ton }\end{array}$ & $\begin{array}{c}\text { zooplankt } \\
\text { on }\end{array}$ & $\begin{array}{c}\text { zoobent } \\
\text { hos }\end{array}$ \\
\hline $\begin{array}{l}\text { Upper course of } \\
\text { the river }\end{array}$ & 3 & 3 & 3 & 3 & 3 \\
\hline $\begin{array}{l}\text { Average flow of } \\
\text { the river }\end{array}$ & 3 & 3 & 3 & 3 & 3 \\
\hline $\begin{array}{l}\text { Lower course of } \\
\text { the river }\end{array}$ & 3 & 3 & 3 & 3 & 3 \\
\hline
\end{tabular}

In total, samples were collected and processed: hydrological -9 , hydrochemical -9 , hydrobiological -33 , including phytoplankton -9 , zooplankton -9 , zoobenthos -9 , macrophytes -3 , and ichthyological-3.

\section{Physical and geographical characteristics of the research area}

The river valley is wide with gentle slopes, a distinct floodplain, swampy in places, with slight slopes, so that the river has a weak current.

The Kirpili river is fed by precipitation and groundwater. The average depth of the studied reservoirs ranges from 120 to $250 \mathrm{~cm}$ [1].

The water in the river belongs to the sulfate class, the sodium group, the second type with mineralization from 2.4 to $6.2 \mathrm{~g} / 1$, hardness from 6.92 to $9.16 \mathrm{mg} \mathrm{EQ} / \mathrm{l}$, alkalinity from 3.98 to $5.12 \mathrm{mg} \mathrm{EQ} / \mathrm{l}$. the content of total nitrogen from 1.12 to $2.36 \mathrm{mg} \mathrm{N} / 1$, total phosphorus from 0.41 to $0.56 \mathrm{mg} \mathrm{P} / 1, \mathrm{pH}$ from 7.8 to 8.4 , oxidability from 9.16 to $13.14 \mathrm{mg}$ $\mathrm{O} / 1$.

In General, the hydrological and hydrochemical regimes of the studied reservoir are favorable for the development of hydrobionts.

\section{Hydrobiological characteristics of reservoirs of the Kirpili river}


Studies have shown that the phytoplankton of riverbed ponds located on the rivers of the Azov-Kuban plain is represented by 125 taxa of algae belonging to 9 groups: Chlorophyta 37 taxa, of which Protococcophyceae - 28, Volvocophyceae - 6, Desmidiales - 3, Bacillariophyta - 33 taxa, Euglenophyta - 16, Cyanophyta - 26, Pyrrophyta - 8, chrysophyta -3 and Xanthophyta -2 taxa. The results obtained are comparable to previous studies within the Azov-Kuban plain [8]. On average, the river's population varies by season from $37862.5 \pm 1.56$ (spring) to $42162.8 \pm 1.32 \mathrm{mil} . \mathrm{kl} / \mathrm{m}^{3}$ (summer), averaging $39929.9 \pm 0.89$ mil. $\mathrm{kl} / \mathrm{m}^{3}$, residual biomass - from $353,1 \pm 0,31$ to $416,7 \pm 0,29 \mathrm{~kg} / \mathrm{ha}$, averaging $383.5 \pm 1.24 \mathrm{~kg} / \mathrm{ha}$ (table. 2).

Table 2. Number and biomass of feed organisms in riverbed ponds of the Kirpili river.

\begin{tabular}{|c|c|c|c|}
\hline & phytoplankton & zooplankton & zoobenthos \\
\hline Season & $\begin{array}{c}\text { Size. } \\
\frac{\mathrm{mil.} \mathbf{k l} / \mathbf{m}^{3}}{\mathrm{~kg} / \mathrm{ha}}\end{array}$ & $\begin{array}{c}\text { Size. } \\
\frac{\text { mil. kl / m }}{3} \\
\mathrm{~kg} / \mathrm{ha}\end{array}$ & $\begin{array}{c}\text { Size. } \\
\text { samples / } \mathrm{m}^{2} \\
\mathrm{~kg} / \mathrm{ha}\end{array}$ \\
\hline \multicolumn{4}{|c|}{ Upper course of the Kirpili river } \\
\hline Spring & $\frac{37123.5 \pm 1.88}{380.3 \pm 0.48}$ & $\frac{811.3 \pm 1.24}{67.7 \pm 1.24}$ & $\frac{355.3 \pm 1.13}{25.1 \pm 0.25}$ \\
\hline Summer & $\frac{42288.6 \pm 1.29}{420.1 \pm 0.31}$ & $\frac{941.5 \pm 1.27}{89.2 \pm 1.22}$ & $\frac{448.6 \pm 1.11}{30.9 \pm 0.29}$ \\
\hline Autumn & $\frac{39566.1 \pm 1.14}{348.1 \pm 0.34}$ & $\frac{1072.1 \pm 1.12}{103.1 \pm 1.38}$ & $\frac{511.7 \pm 1.76}{28.8 \pm 0.29}$ \\
\hline Average: & $\frac{39659.7 \pm 0.78}{382.8 \pm 1.21}$ & $\frac{941.6 \pm 1.31}{86.6 \pm 1.42}$ & $\frac{438.5 \pm 1.34}{28.3 \pm 1.43}$ \\
\hline \multicolumn{4}{|c|}{ Middle course of the Kirpili river } \\
\hline Spring & $\frac{37862.5 \pm 1.56}{380.7 \pm 0.43}$ & $\frac{815.7 \pm 1.18}{67.9 \pm 1.12}$ & $\frac{389.5 \pm 1.24}{26 \pm 0.22}$ \\
\hline Summer & $\frac{42162.8 \pm 1.32}{416.7 \pm 0.29}$ & $\frac{936.4 \pm 1.21}{89.1 \pm 1.31}$ & $\frac{456.7 \pm 1.12}{31 \pm 0.34}$ \\
\hline Autumn & $\frac{39764.3 \pm 1.23}{353.1 \pm 0.31}$ & $\frac{1098.3 \pm 0.98}{103.3 \pm 1.26}$ & $\frac{524.8 \pm 1.62}{29 \pm 0.28}$ \\
\hline Average: & $\frac{39929.9 \pm 0.89}{383.5 \pm 1.24}$ & $\frac{950.1 \pm 0.92}{86.8 \pm 1.14}$ & $\frac{457.8 \pm 0.96}{28.7 \pm 1.30}$ \\
\hline \multicolumn{4}{|c|}{ Lower course of the Kirpili river } \\
\hline Spring & $\frac{38224.5 \pm 1.17}{389.3 \pm 0.51}$ & $\frac{878.7 \pm 1.61}{69.9 \pm 1.55}$ & $\frac{379.9 \pm 1.23}{25.7 \pm 0.38}$ \\
\hline Summer & $\frac{42971.1 \pm 1.12}{417.1 \pm 0.25}$ & $\frac{959.3 \pm 1.29}{89.9 \pm 1.27}$ & $\frac{479.8 \pm 1.22}{31.5 \pm 0.66}$ \\
\hline Autumn & $\frac{41127.1 \pm 1.77}{355.7 \pm 0.39}$ & $\frac{1112.4 \pm 1.12}{104.1 \pm 1.27}$ & $\frac{557.1 \pm 1.71}{29.3 \pm 0.5}$ \\
\hline Average: & $\frac{40774.3 \pm 1.13}{387.4 \pm 1.25}$ & $\frac{983.5 \pm 1.23}{88.0 \pm 1.24}$ & $\frac{472.3 \pm 1.14}{28.8 \pm 0.27}$ \\
\hline
\end{tabular}

Zooplankton is represented by three typically planktonic groups of organisms: Rotatoria, Copepoda, and Cladocera [9, 10]. The zooplankton species analysis identified invertebrates belonging to 24 taxa: Rotatoria-16, Copepoda-4, Cladocera -4 . The average biomass of zooplankton in reservoirs ranges from $67,9 \pm 1,12$ to $103,3 \pm 1,26 \mathrm{~kg} / \mathrm{ha}$, averaging $86,8 \pm 1,14 \mathrm{~kg} / \mathrm{ha}$.

The bottom fauna is mainly represented by Oligochaeta and Chironomidae, as well as larvae of water beetles, dragonflies and mollusks. The residual biomass of forage zoobenthos (Oligochaeta, Chironomidae) of the studied reservoirs ranges from $26 \pm 0,22$ to $31 \pm 0,34$ samples $/ \mathrm{m}^{2}$, averaging $28.7 \pm 1.30 \mathrm{~kg} / \mathrm{ha}$ (table. 2 ). 
Water vegetation within the channel part of the studied channel ponds of the Kirpili river is represented by 19 taxa. The dominant species is Pharagmites communis, it creates dense phytocenoses along the banks, as well as in the form of separate Islands in various parts of the reservoir.

Subdominant species of hard vegetation are Typha latifolia and T. Angustifolia. In addition to these species, scairpus cacustris, S. Triquetra, and Sparganium ramosum are observed in all lowland reservoirs. The bottom of riverbed ponds to some extent (from 30 to $65 \%$ of the water area) is covered with soft underwater vegetation, which is mainly represented by such species as: Myriophyllum spicatum, Potamogeton perfoliatus, $R$. lucenus and P. pectinatus. Taking into account the different density of water vegetation covering the area of ponds, its total biomass is from 10 to $45 \mathrm{~kg} / \mathrm{m}^{2}$.

The degree of overgrowth of the reservoir has a different effect on the entire ecosystem. So, if no more than a quarter of the water area is occupied by water and near-water plants, its positive influence is noted, which is expressed in the formation of primary production of trophic bonds, normalization of the gas composition of the water environment and strengthening of the banks. Excessive vegetation development, on the contrary, leads to waterlogging, changes in the hydrochemical parameters of the environment, a reduction in the area of fish feeding, etc. All these factors, in the end, have a negative impact on the fish productivity of the reservoir.

In the conditions of a large number of water and near-water higher plants within the reservoir, it is advisable to make stocking with young white Amur. This species is a natural Meliorator, it is able to reduce the amount of higher vegetation and at the same time increase the yield of valuable fish products.

\section{Ichthyological characteristics of the Kirpili river}

The species composition of the ichthyofauna of the Kirpili river includes 26 species of fish, the most valuable of which are carp (Cyprinus carpio), bream (Abramis brama), walleye (Sander lucioperca), but their number is insignificant, the most numerous are low - value roach (Rutilus rutilus), Rudd (Scardinius erythrophthalmus), silver carp (Sagassiis auratus gibelio), river carp perch (Perca fluviatilis) and weed fish species - bleak (Alburnus alburnus), sand goby (Neogobius fluviatilis), common ruff (Gymnocephalus cernuus), belica (Leucaspius delineatus) and others. The occurrence of fish in different parts of the Kirpili river had certain differences (table. 3).

According to their biology, all fish species are typically freshwater species and belong to spring-spawning fish that lay eggs on various types of substrates: vegetating vegetation, underwater objects, and plant rhizomes. During floods and flooding of flood zones, favorable conditions are created for their spawning, since the preferred conditions for these types of fish are low water speed $(0.1-0.2 \mathrm{~m} / \mathrm{s})$, small depths $(0.3-0.5 \mathrm{~m})$ and relatively high water temperature $\left(18-20^{\circ} \mathrm{C}\right)$, freshly filled vegetation $[11,12]$.

These fish are limnophilic species, preferring sections of rivers with a small current. They do not make significant trophic and spawning migrations. The results of numerous studies of the biology of valuable commercial fish species indicate that these species are characterized by a relatively short life span. In terms of age, the populations are dominated by individuals of three to five years of age-more than $85 \%$, while the proportion of older ages is about $1-2 \%$.

Table 3. Species composition and occurrence of Kirpili river fish.

\begin{tabular}{|l|l|l|r|}
\hline \multirow{2}{*}{ Species } & \multicolumn{3}{|c|}{ The section of the river } \\
\cline { 2 - 4 } & Upstream & Middle course & Lower course \\
\hline
\end{tabular}




\begin{tabular}{|c|c|c|c|}
\hline Cyprinus carpio & ++ & ++ & ++ \\
\hline Abramis brama & ++ & +++ & +++ \\
\hline Sander lucioperca & + & ++ & ++ \\
\hline Rutilus rutilus & ++ & +++ & +++ \\
\hline Rutilus rutilus heckeli & ++ & ++ & +++ \\
\hline Scardinius erythrophthalmus & ++ & ++ & ++ \\
\hline Carassius auratus gibelio & ++ & ++ & ++ \\
\hline Carassius carassius & ++ & ++ & ++ \\
\hline Esox lucius & +++ & +++ & +++ \\
\hline Leuciscus idus & +++ & ++ & ++ \\
\hline Mylopharyngodon piceus & - & + & + \\
\hline Ctenopharyngodon idella & + & ++ & ++ \\
\hline Hypophthalmichthys molitrix & ++ & ++ & ++ \\
\hline Hypophthalmichthys nobilis & ++ & ++ & ++ \\
\hline Perca fluviatilis & +++ & +++ & +++ \\
\hline Gymnocephalus cernuus & ++ & ++ & ++ \\
\hline Vimba vimba vimba & ++ & ++ & ++ \\
\hline Pelecus cultratus & + & ++ & ++ \\
\hline Tinca tinca & +++ & ++ & ++ \\
\hline Cobitis taenia & ++ & ++ & ++ \\
\hline Silurus glanis & ++ & ++ & ++ \\
\hline Alburnus alburnus & ++ & ++ & ++ \\
\hline Neogobius fluviatilis & ++ & - & + \\
\hline Gymnocephalus cernuus & ++ & ++ & ++ \\
\hline Liza haematocheilus & + & ++ & ++ \\
\hline Leucaspius delineatus & +++ & +++ & +++ \\
\hline \multicolumn{4}{|l|}{$\begin{array}{l}\text { Notes: } \\
1-+++ \text { numerous species } \\
2-++ \text { normal view } \\
3-+ \text { rare species } \\
4-- \text { the species was not dete }\end{array}$} \\
\hline
\end{tabular}

As you can see, the ichthyofauna of the river is represented mainly by low-value fish species (Sagassiis auratus gibelio, Rutilus rutilus, Scardinius erythrophthalmus, Perca fluviatilis, etc.). Valuable commercial species (Cyprinus carpio, Abramis brama, Sander lucioperca) are few in number. To reduce the number of low-value and weed species of fish, it is necessary to conduct specialized fishing in the spring on spawning grounds and in the summer in places of their highest concentration (in shallow, well-warmed coastal zones). Defusing the number of non-commercial fish will significantly reduce the tension of 
food relations, and will also allow valuable fish species to more effectively use the available feed resources.

Low-value fish species, feeding on the same forage organisms as valuable fish species (carp, herbivorous fish), give a very low increase in ichthyomass.

Thus, studies conducted on riverbed reservoirs of the Kirpili river have shown that feed resources are developing well. However, from the point of view of aquaculture, they are not used rationally. Invertebrate animals of the water column, EPI-and infauna are mostly consumed by fish, which are economically low-value and weedy. Phytoplankton and higher aquatic vegetation (soft underwater) are practically not used by local fish species. This colossal mass of organic matter, when dying off, worsens the conditions of fish feeding and contributes to the accumulation of silt. In this regard, in reservoirs there is an intensive process of accumulation of productive silt with a high proportion of planktogenic detritus, which can serve as a food component for pilengas and partially for white and variegated silver carp.

The rivers of the flat part of the North-West Caucasus are characterized by high indicators of primary feed production, but due to the fact that it is used by low-value fish species, the overall fish productivity of these reservoirs is not great. As it is known, the yield of fish products is determined not by the residual biomass of forage organisms, but by the amount of their annual (seasonal) production.

The obtained data on the production of phytoplankton, zooplankton and zoobenthos are indicative, but they can be used to directly determine the potential fish productivity of reservoirs (table.4).

Table 4. Potential fish production of Kirpili riverbed ponds.

\begin{tabular}{|c|c|c|c|c|c|}
\hline \multicolumn{6}{|c|}{ Group of organisms } \\
\hline Indicators & $\begin{array}{c}\text { phytoplank- } \\
\text { ton }\end{array}$ & $\begin{array}{l}\text { zooplank- } \\
\text { ton }\end{array}$ & $\begin{array}{l}\text { zooben- } \\
\text { thos }\end{array}$ & $\begin{array}{l}\text { macro- } \\
\text { phytes }\end{array}$ & in total \\
\hline $\begin{array}{l}\text { Residual biomass, } \mathrm{kg} / \\
\text { ha }\end{array}$ & 370.98 & 63.54 & 80.70 & 103700 & \multirow{6}{*}{1427} \\
\hline P / B-coefficient & 80 & 20 & 6 & 1.1 & \\
\hline Production, $\mathrm{kg} / \mathrm{ha}$ & 29678 & 1271 & 484 & 114070 & \\
\hline Use of products, $\%$ & 50 & 60 & 50 & 25 & \\
\hline Feed ratio & 19 & 10 & 6 & 50 & \\
\hline Potential & 781 & 76 & 40 & 570 & \\
\hline
\end{tabular}

When determining whether fish production and potential yield in forage base many researchers came from the annual production of the plankton and benthos and established which part of the production of food organisms eaten by fish using feed efficiency of plankton and benthos, directly calculating the value of the annual growth of ichthyomass $[14,15,16]$.

Given that fish use the food supply to a very different extent, depending on a number of reasons related to both the quality of the consumer (type, age, search ability, physiological state, etc.) and feed conditions (availability of feed, water temperature, illumination, distribution of feed, etc.), we allow fish to use $50 \%$ of phytoplankton products, $60 \%$ of zooplankton, $50 \%$ of zoobenthos products, and $25 \%$ of macrophyte products.

Calculations based on available feed resources show that on average, $1427 \mathrm{~kg}$ of fish products can be obtained from natural feed from each hectare of water area.

To obtain this fish product, it is necessary to carry out reclamation catching of lowvalue and predatory fish species and only then proceed to the directed formation of the commercial ichthyofauna of the reservoir by stocking it with valuable fast-growing fish species $[17,18]$. 
Stocking should be made by yearlings Hypophthalmichthys molitrix, Hypophthalmichthys nobilis, Ctenopharyngodon idella, as additional Cyprinus carpio, Mylopharyngodon piceus, Liza haematocheila, Polyodon spathula, etc.) with an individual weight of not less than $25-30 \mathrm{~g}$, at the rate of 1500 copies/ha of white silver carp, 300 copies/ha of variegated silver carp, 250 copies/ha white Amur, at the rate of $250 \mathrm{copies} / \mathrm{ha}$ of carp. In the second year of the achievement of individual fish weight $1,0-1,5 \mathrm{~kg}$ and at the exit from the landing of the fish $50 \%$ fish and white silver carp will be $750 \mathrm{~kg} / \mathrm{ha}$, a motley silver carp - $225 \mathrm{~kg} / \mathrm{ha}$, white Amur $-187 \mathrm{~kg} / \mathrm{ha}$, carp $-187 \mathrm{~kg} / \mathrm{ha}$. in addition due to the additional fish you can get at $20-30 \mathrm{~kg} / \mathrm{ha}$ of high quality fish products. In total, the actual natural fish production will reach more than $1350,0 \mathrm{~kg} / \mathrm{ha}$, which is quite consistent with the estimated potential.

Thus, calculations based on available feed resources show that on average, $1400 \mathrm{~kg}$ of high-quality fish products can be obtained from natural feeds from each hectare of water area.

\section{References}

1. O.N. Suslov, Steppe rivers of the Krasnodar territory (Kuban State Agrarian University, Krasnodar, 2015)

2. G.G. Matishov, E.N. Ponomareva, M.N. Sorokina, International youth scientific conference "Oceanography in the XXI century: current facts, models, methods and tools" (UNC RAS, Rostov n/D, 2017)

3. Z. Rajić, N. Vignjević-Đorđević, S. Čanak, Economics of Agriculture 4(63), 1445 1458 (2016)

4. L. Kalinina, I. Zelenskaya, SHS Web of Conferences 55, 01008 (2018)

5. G.A. Moskul, Yu.I. Kovalenko, N.G. Pashinova, O.A. Bolkunov, Materials of the VII Charter of the International conference (YugNIRO, Kerch, 2012)

6. M. Castellani, R. Rosland, A. Urtizberea, Q. Fiksen, Ecological Modelling 251, 54-63 (2013)

7. O.A. Bolkunov, G.A. Moskul, N.G. Pashinova, Natural and technical Sciences 4, 4854 (2015)

8. A.V. Abramchuk, G.A. Moskul, N.G. Pashinova, Natural and technical Sciences 10(124), 75-77 (2018)

9. N.G. Pashinova, G.A. Moskul, O.A. Bolkunov, Proceedings of the Kuban state agrarian University 49, 22-25 (2014)

10. O. Ovaskainen, B. Weigel, O. Potyutko, Y. Buyvolov, Ecological Indicators, 476-482 (2019)

11. G.I. Karnaukhov, Biological diversity: study, conservation, restoration, rational use: materials of the scientific and practical International conference (Arial, Kerch, 2018)

12. G.G. Matishov, P.A. Balykin, P.P. Geraskin, Results of ichthyological studies on the Lower Volga (UNC RAS, Rostov-on-don, 2015)

13. M. Pahlow, P.R. Van Oel, M.M. Mekonnen, A.Y. Hoekstra, Science of The Total Environment, 847-857 (2015)

14. M.E. Cunha, H. Quental-Ferreira, A. Parejo, S. Gamito, L. Ribeiro, M. Moreira, I. Monteiro, F. Soares, P. Pousão-Ferreira, Aquaculture, 734297 (2019)

15. Z. Adámek, M. Mössmer, M. Hauber, Aquaculture, 734261 (2019) 
16. G.A. Moskul, A.V. Abramchuk, N.G. Pashinova, Biological, ecological and morphological features of the silver carp (Hypophthalmichthys molitrix (Val., 1844) (Kuban basin. Scientific research of the SCO countries: synergy and integration, Beijing, 2019)

17. G.A. Moskul, N.G. Pashinova, A.V. Abramchuk, Hypophthalmichthys nobilis (Richardson, 1846) (Kuban basin, Scientific research of the SCO countries: synergy and integration. Beijing, 2019) 